INTERNATIONAL DESIGN CONFERENCE - DESIGN 2018

https://doi.org/10.21278/idc.2018.0395

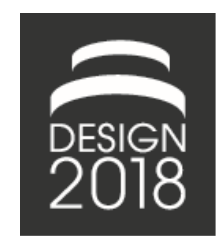

\title{
THINKING STYLES IN PRODUCT OPPORTUNITY RECOGNITION - A RATHER ENTREPRENEURIAL POINT OF VIEW
}

\author{
Z. Zagorac and C. Marxt
}

\begin{abstract}
Actual cognitive strategies in relation to identifying new business opportunities have rarely been researched. This paper investigates the roles of a pair of cognitive strategies - divergent and convergent thinking - in the context of the type and process of the product opportunity recognition.
\end{abstract}

Keywords: new product development, human behaviour, design process, divergent thinking, convergent thinking

\section{Introduction}

How are opportunities for new products and services recognized? What kind of thinking style is predominant in these early stages of their life cycle? How do innovations, designer and entrepreneurs start into their process of creating new products or services? These questions have been in the focus of research in the area of product innovation for more than one decade, usually from a designer point of view with a focus on creativity or innovation. For this paper we want to expand the horizon and look at how start-up entrepreneurs go about this problem. These entrepreneurs quite often create new businesses based on either a business model or a product/service idea.

Opportunity recognition builds the initial stage of the innovation activities and is understood as the initial stage of the process of creating new products / services / and/or business (models) (e.g. business model canvases). Without preceding opportunity recognition, innovative and commercially viable products, services or business models are unlikely to come into existence. It has been acknowledged that opportunity recognition starts with individual cognition, in which (nascent or current entrepreneurs) begin to conceive a match between potential market needs and corresponding resources (e.g., technologies) to satisfy those needs (Grégoire and Shepherd, 2011). One aspect of cognition is creative thinking, through which entrepreneurs identify novel and useful ideas (Ward, 2004; Baron and Ward, 2004). Although creativity - as important factor in opportunity recognition - has already been discussed by several authors (Kirzner, 1999; Corbett, 2007; Hansen et al., 2011), empirical studies on the impact of creative thinking and the way in which it influences opportunity recognition are rather scarce. Only recent studies have demonstrated the positive role of the divergent thinking ability (a widely used measure for creative thinking) for the identification of more innovative opportunities (e.g., Gielnik et al., 2012). It requires more than just coming up with a unique idea to fulfill the requirements of an innovative opportunity. Entrepreneurial people will likely have to analyze new information (e.g., about new technologies or market trends), to draw proper conclusions and to evaluate their conclusions in order to recognize the opportunities and their potential commercialization value. All these processes information analysis, drawing conclusions, evaluating new information or ideas - pertain to convergent thinking, which is often seen as the antipode of creative thinking (Cropley, 2006). While organizational 
creativity literature has acknowledged the conjoint roles of divergent and convergent thinking (Cropley and Cropley, 2015) entrepreneurship research has not yet investigated their joint effects for opportunity recognition and product innovation.

\section{Defining opportunity recognition}

Opportunity recognition builds the initial stage of entrepreneurial activities (Shane and Venkataraman, 2000; Ardichvili et al., 2003). It triggers the formation of start-up firms as well as the renewal of incumbent firms. Three general views on opportunity recognition have emerged: 1) the discovery view, which treats opportunities as existing objects, waiting to be identified by certain individuals that possess idiosyncratic knowledge or information (Kirzner, 1999), 2) the creation view, in which the individual creates or enacts opportunities by its behavior, and 3) the pure "recognition" view, according to which individuals conceive a match between potential markets needs and resources to satisfy those needs (Baron, 2006; Grégoire and Shepherd, 2011). In our opinion opportunity recognition should be regarded as an iterative, creative process, which starts with some sort of preparation - such as problem identification or the identification of a new technology - that triggers the recognition and development of an entrepreneurial opportunity at a certain point in time along that process. Therefore we follow the perspective of a more pragmatic view, according to which opportunity recognition represents a dynamic process which emerges by means of both discovery and recognition of circumstances in the external world and by proactive formation of new ideas (Ardichvili et al., 2003; Dimov, 2011; Gemmell et al., 2012). This process is therefore complex and multi-faceted because it undergoes a stream of transformations, evaluations and reconsiderations by both the entrepreneur and sparring partners (Gemmell et al., 2012). Nevertheless, the initial trigger of this process starts with individual reasoning, which is why a cognitive umbrella will be deployed as the major theoretical approach to better understand opportunity recognition (Grégoire et al., 2015).

\section{Cognitive activities in early stages of the entrepreneurial process}

The cognitive approach has become considerably important for the investigation of opportunity recognition (Baron and Ward, 2004; Grégoire et al., 2011). Cognition deals with questions related to reasoning abilities, thinking styles, decision-making abilities and specific cognitive characteristics (cf. Grégoire et al., 2015). Cognition, therefore, acts as a boundary-spanning platform that integrates different theories that are mainly adopted from cognitive psychology (Mitchell et al., 2004).

An important cognitive impetus for the recognition process is the acquisition of new information such as information about technological trends or social changes (Corbett, 2007). In this context, prior knowledge and new information of markets and technologies have been identified as key factors (Arentz et al., 2012). However, these studies have rarely addressed the question of how individuals actually use their specific knowledge. Recognizing an opportunity is not simply accomplished by possessing a great deal of knowledge but via leveraging knowledge and new information (Ucbasaran et al., 2008; Grégoire et al., 2011). Thus, it is a promising avenue to look at the underlying dynamics as they unfold. Recent studies have addressed the intertwined roles of knowledge and cognitive processes. For example, Ko and Butler (2006) demonstrated in a study with technology entrepreneurs the positive role of a specific type of creative thinking. According to that, bisociative thinking mediates the relation of diverse technological knowledge and the recognition of an opportunity by connecting the knowledge concepts of at least two different technological domains. Similarly, Gielnik et al. (2014) revealed that higher divergent thinking ability levels in combination with either entrepreneurial experience (resulting in knowledge) or new information has a positive impact on the identification of innovative opportunities. Gielnik et al. (2012) also assumed that general intelligence would have an effect on those opportunities. However, contrary to other assumptions, these authors could not find support for this hypothesis. They argue that intelligence is associated with convergent thinking, and would cause individuals to search for the best solution rather than coming up with new and original ideas, which is why they conclude that convergent thinking is not the driving mechanism behind opportunity recognition. However, Gielnik et al. (2012) investigated solely ability levels, and not the actual application of convergent thinking.

Another stream of literature has examined cognitive dynamics from a learning theory perspective (Corbett, 2005; Dimov, 2007). The key assumption is that entrepreneurial opportunities can be 
recognized by using different learning styles. According to the empirical findings of Dimov (2007), entrepreneurs, who digest new information thoroughly, are more prone to identify opportunities, regardless whether they prefer a divergent or convergent thinking learning styles. However, entrepreneurs, who think preferably in a divergent manner, can identify opportunities independent of how much they reflect upon new information. Corbett (2007), on the other hand, has shown that individuals can identify opportunities also by means of convergent thinking if they have a sound knowledge of a problem to be tackled. In this study he neither controlled for innovativeness nor profitability but solely emphasized the quantity of opportunities identified. Those studies have not shown actual thinking patterns but asked for self-reporting preferences (learning styles). As it seems that divergent thinking results in particularly novel ideas, it is necessary to examine if convergent thinking in combination with divergent thinking can result in a higher propensity of both commercially viable and innovative opportunities. Grounding on the current state of research, we hypothesize that recognizing opportunities, as a multi-faceted process, is enabled by both divergent and convergent thinking at the individual level, however yet it has to be explored in which ways and in respect of the context. Therefore, it is a promising avenue to examine how those joint roles of divergent and convergent thinking can be characterized.

\section{Research methodology}

\subsection{Exploratory case studies}

This paper builds on an exploratory multiple case-study analysis, which employs a mix of qualitative and quantitative methods. The purpose of the explorative approach is to investigate the role of divergent and convergent thinking in the context of the opportunity recognition processes without predefined hypotheses and by that, enabling theory development as opposed to theory testing. The advantage of case studies is that they "emphasize the rich, real-world context in which the phenomena occur" (Eisenhardt and Graebner, 2007). Conducting multiple-case studies is a suitable method to increase the generalizability without sacrificing the benefits of the exploratory research (Yin, 2009). The qualitative investigation is supported by standardized online-based divergent and convergent thinking ability tests. Online-based tests have been selected as most efficient solution to access the divergent and convergent

thinking capacities, in which the participant could flexibly choose time and place of the assessment for recruitment purposes. Both test admissions were provided by a developer of psychometric assessments for professional and academic purposes. The focus of the qualitative part of investigation lies on exploring different application patterns of divergent and convergent thinking. The quantitative investigation's goals are to first test, whether ability levels of divergent and convergent thinking have an impact on the quality of the identified opportunities (by means of expert rating), and second, whether the findings from the qualitative study can also be supported statistically.

\subsection{Multiple-case study analysis}

\subsubsection{Data collection}

While quantitative investigations seek randomness, qualitative investigations typically seek purposive samples, suitable for theoretical generalizability. As we investigate individual level capacities, we focused on entrepreneurs in conjunction with their opportunity story rather than on firms. Researchers typically look for opportunity cases that have not only been recognized but exploited in some way as it would be otherwise too difficult to identify such cases (Siegel and Renko, 2012). Practically, those persons could be found in many different areas, such as in incubators, technology parks, in educational entrepreneurship programs, and at business idea contests. We utilized all of these avenues for the acquisition of participants, focusing on the four-boarder-region of Austria-Germany-LiechtensteinSwitzerland. Finally, we recruited 32 entrepreneurs, all of them male, even though we had contacted about $20 \%$ female entrepreneurs. The first source of evidence consists of qualitative, semi-structured interviews, using an interview guide that was developed and tested prior to the interviews to make the case studies comparable (Yin, 2009). This includes key questions related to import aspects about which the entrepreneur had reflected over, and most importantly about ways of acquiring new information, 
ways of making sense of that information, ways of coming up with new ideas, combinations or conclusions. Furthermore, we asked the entrepreneur to recall the sequence of thoughts and particular events with respect to the opportunity recognition by means of either drawing a mind-map or making notes prior to the interview.

\subsubsection{Data analysis and coding themes}

The data analysis followed a mix of inductive and deductive approaches: data analysis as suggested by Eisenhardt (1989), Miles and Huberman (1984) and pattern matching logic as suggested by Yin (2009). The first cycle of coding served as within-case analysis to make full sense of each case story, its context and to enable the categorization into the three opportunity types. The second coding cycle was dedicated to text related to cognitive processes, which the entrepreneurs utilized (or could remember to have utilized) during each the opportunity recognition process. Clearly, such a retrospective categorization cannot fulfill the criteria of completeness for each case nor can it guarantee validity in a statistical sense. However, from a qualitative point of view, it can establish a contextual and subjective meaningfulness, in-depth understanding of the cognitive themes that are being investigated, and provide a basis for crosscase comparison for different, contextual patterns.

After identifying 105 low-level codes and abstracting them to middle-level codes building the emergent cognitive, the middle-level codes were grouped to what either would be attributed to a convergent or divergent process. The top-level codes served as a basis for cross-case analysis to identify similarities and differences between the cases. We followed Cropley and Cropley's definitions and examples of those two cognitive modes for this aggregation. Table 1 outlines some examples of middle level codes, their descriptions and example references. Due to confidentiality reasons the study participants and the corresponding original quotes were assigned Greek names.

Table 1. Coding structure

\begin{tabular}{|c|c|c|}
\hline Codes & Description & Example reference \\
\hline CT: Analyzing & $\begin{array}{l}\text { Systematic and often in-depth analysis of } \\
\text { new, mainly written information; e.g. about a } \\
\text { market, competition or technology }\end{array}$ & $\begin{array}{l}\text { "So I wanted to know, how it does work } \\
\text { exactly, who pays for whom for what etc. } \\
\text { etc., to find the details. The third step was } \\
\text { then to see the situation with competitors, } \\
\text { how many players are there." (Crius) }\end{array}$ \\
\hline $\begin{array}{l}\text { CT: } \\
\text { Categorizing }\end{array}$ & $\begin{array}{l}\text { Structuring something; usually a preparation } \\
\text { for some other activity; e.g. sorting new } \\
\text { information with regard to a technical } \\
\text { problem }\end{array}$ & $\begin{array}{l}\text { "So I tried to categorize the things and to } \\
\text { break down the tasks." (Lykourgos) }\end{array}$ \\
\hline $\begin{array}{l}\text { CT: } \\
\text { Choosing }\end{array}$ & $\begin{array}{l}\text { Choosing between two or more options; e.g. } \\
\text { ideas or general directions, or deciding upon } \\
\text { an activity; e.g. to start the business an } \\
\text { conscious evaluation }\end{array}$ & $\begin{array}{l}\text { "When we saw this cost structure and the } \\
\text { possibilities of the many colors } \\
\text { (cosmetics) you can realize, yes, actually } \\
\text { this is the right product to start with." } \\
\text { (Charon) }\end{array}$ \\
\hline $\begin{array}{l}\text { DT: } \\
\text { Associating }\end{array}$ & $\begin{array}{l}\text { Initial connection of two different themes, } \\
\text { often from distant fields, in an unstructured, } \\
\text { non-systematic and non-conclusive way }\end{array}$ & $\begin{array}{l}\text { "And then we thought we like gaming and } \\
\text { this is possible be become an app" } \\
\text { (Lykourgos) }\end{array}$ \\
\hline DT: Exploring & $\begin{array}{l}\text { Non-systematic exploration of different } \\
\text { (general) directions concerning an issue, often } \\
\text { with the idea to get an overview or a pool of } \\
\text { possibilities; e.g., exploring trends, markets, } \\
\text { technologies }\end{array}$ & $\begin{array}{l}\text { "Why don't we professionalize lighting for } \\
\text { plants?" (Perseus) }\end{array}$ \\
\hline $\begin{array}{l}\text { DT: } \\
\text { Ideating }\end{array}$ & $\begin{array}{l}\text { Generation of different ideas out of a single } \\
\text { reference point; e.g., out of an aspect of a } \\
\text { problem, a new finding or a chosen } \\
\text { technology }\end{array}$ & $\begin{array}{l}\text { "Based on this new knowledge I } \\
\text { developed different, I would say, services, } \\
\text { but not very clear, it was clear maybe one } \\
\text { year later how they would look like" } \\
\text { (Zeus) }\end{array}$ \\
\hline
\end{tabular}


Comparing the initial cognitive mechanisms by opportunity type, we found interesting initial results. People with business model opportunities started prevalently with convergent thinking processes, whereas opportunities for new products have been started by either convergent or divergent thoughts; however, more often with divergent mechanisms.

Figure 1 illustrates all opportunity cases in relation to the thinking mechanisms that triggered the opportunity recognition process. We furthermore differentiate by technological intensity of the context the opportunities relate to - the black circles show high-tech industries, the white circles display lowtech industry contexts.

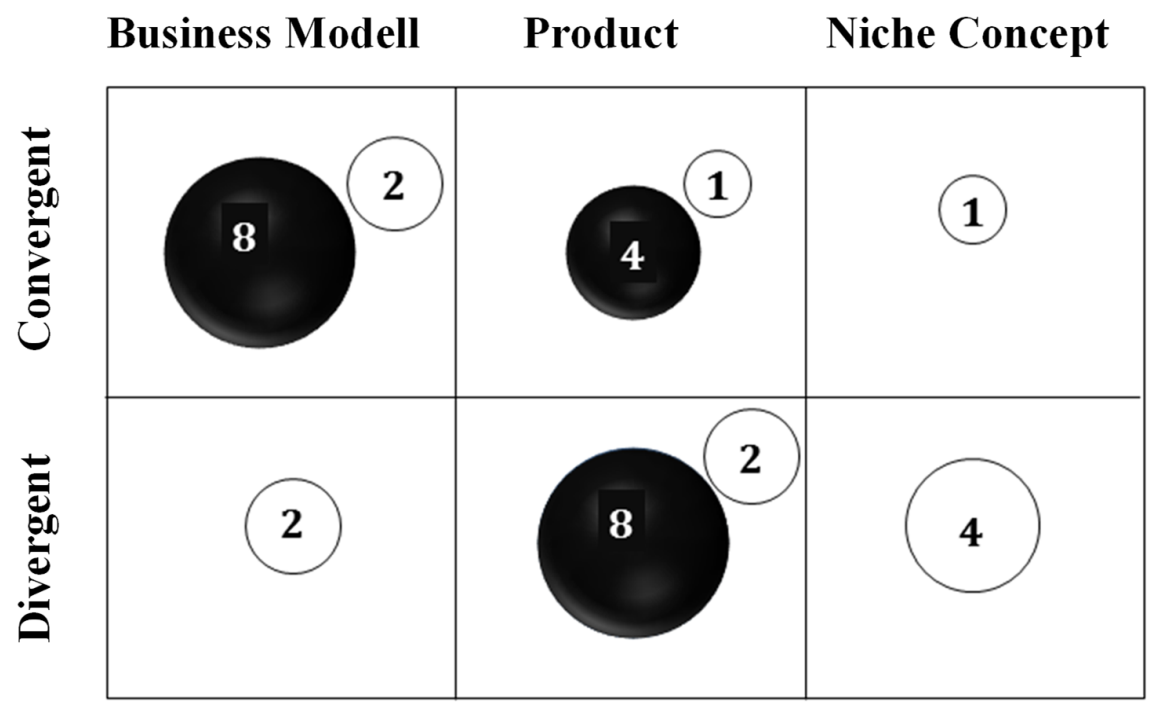

Figure 1. Triggers in relation to opportunity type

The in-depth case analysis has revealed two interesting patterns. The analysis focused on three different topics: business models, products and niche concepts. For the purpose of this paper we focus on the product category.

Product-driven opportunities have been initiated in 10 of 15 times by divergent thinking processes, suggesting that divergent thinking plays a much greater role for new product ideas than for new business models. Also when it comes to high-tech environments, divergent triggers commence twice as often the process ( 8 of 12 cases). Two commonalities could be identified here: First, this group of individuals shows a smaller percentage of those having a clear intention to become entrepreneur (four of 10). Second, and probably more importantly, in this group the process took a different path and presented a richer context. Seven opportunities were initiated in a surrounding of other people. Even though the entrepreneur came up with the idea by himself - other people (such as colleagues) took an active part in that process, in such that the idea emerged out of a conversation about topics related to the later opportunity and prior experience. For example, Perseus, who has an engineering degree in photonics, talked with his good friends about their joint hobby: gardening. Additionally, both had user-experience in such a way that they experimented with good lighting for in-door plants, the results being: "Why don't we professionalize lighting for plants?" (Perseus, Case 21). Such cognitive processes, which we code as "wondering", have been identified throughout many cases of divergent thinking. In accordance to previous work (e.g. Dyer et al., 2008) questioning plays an important preceding role for ideating and creativity. The other mechanisms, which would typically occur at the early phase of opportunity recognition were 1) "exploring" new (business, market, technological) fields, 2) building rather distant "associations" between different knowledge fields, and 3) "imagining" future visions of solutions or business scenario. Only one person (case 16, Cronos) reported to have had a sparking idea after some funny experimentation without clarity of how and why exactly the idea emerged. Table 2 gives a summary of all cases of that category. 
Table 2. Case summary report on new product opportunities

\begin{tabular}{|c|c|c|c|}
\hline Case & Opportunity story & Initial trigger & $\begin{array}{l}\text { Cognitive } \\
\text { pattern }\end{array}$ \\
\hline $\begin{array}{l}\text { 13. Aeron } \\
\text { Electronic } \\
\text { Equipment }\end{array}$ & $\begin{array}{l}\text { Direct customer (from other business) } \\
\text { request, which has been addressed and } \\
\text { solution has been developed as response. }\end{array}$ & $\begin{array}{l}\text { Convergent; } \\
\text { evaluation of } \\
\text { request }\end{array}$ & Balanced \\
\hline $\begin{array}{l}\text { 14. Nestor } \\
\text { Electronic } \\
\text { Equipment }\end{array}$ & $\begin{array}{l}\text { Product idea has been developed due to } \\
\text { own user need and by means of knowledge } \\
\text { of technological possibilities. }\end{array}$ & $\begin{array}{l}\text { Convergent; } \\
\text { systematic } \\
\text { ideation }\end{array}$ & Convergent \\
\hline $\begin{array}{l}\text { 15. Thanatos } \\
\text { Electronic } \\
\text { Equipment }\end{array}$ & $\begin{array}{l}\text { Idea arose because of knowledge of existing } \\
\text { technological solutions and wondering, if } \\
\text { there is another way to produce it more } \\
\text { efficiently. }\end{array}$ & $\begin{array}{l}\text { Divergent; } \\
\text { wondering }\end{array}$ & $\begin{array}{l}\text { Rather } \\
\text { divergent }\end{array}$ \\
\hline $\begin{array}{l}\text { 16. Kronos } \\
\text { Electronic } \\
\text { Equipment }\end{array}$ & $\begin{array}{l}\text { After experimenting with different } \\
\text { technologies, an idea out of fun proved to } \\
\text { work well, leading to the recognition of } \\
\text { market potential. }\end{array}$ & $\begin{array}{l}\text { Divergent; } \\
\text { sparking idea }\end{array}$ & Divergent \\
\hline $\begin{array}{l}\text { 17. Castor } \\
\text { Electronic } \\
\text { Equipment }\end{array}$ & $\begin{array}{l}\text { Discovery of technological possibility } \\
\text { (based on exploration) and solution for a } \\
\text { specific market problem. }\end{array}$ & $\begin{array}{l}\text { Divergent; } \\
\text { exploring }\end{array}$ & $\begin{array}{l}\text { Rather } \\
\text { convergent }\end{array}$ \\
\hline $\begin{array}{l}\text { 18. Phobos } \\
\text { Electronic } \\
\text { Equipment }\end{array}$ & $\begin{array}{l}\text { The starting point was a research project, in } \\
\text { which several ideas for new products came } \\
\text { up and have later been shaped to } \\
\text { applications. }\end{array}$ & $\begin{array}{l}\text { Divergent; } \\
\text { ideating }\end{array}$ & $\begin{array}{l}\text { Rather } \\
\text { convergent }\end{array}$ \\
\hline $\begin{array}{l}\text { 19. Ailill } \\
\text { Energy } \\
\text { Supplies }\end{array}$ & $\begin{array}{l}\text { Product idea arose out of prior technology, } \\
\text { market and user knowledge, resulting in a } \\
\text { user-need specific "vision". }\end{array}$ & $\begin{array}{l}\text { Divergent; } \\
\text { imagining }\end{array}$ & Balanced \\
\hline $\begin{array}{l}\text { 20. Lykourgos } \\
\text { Game } \\
\text { Application }\end{array}$ & $\begin{array}{l}\text { Product idea arose out of distant association } \\
\text { of technological knowledge and own user } \\
\text { experiences (gaming). }\end{array}$ & $\begin{array}{l}\text { Divergent; } \\
\text { associating }\end{array}$ & Balanced \\
\hline $\begin{array}{l}\text { 21. Perseus } \\
\text { Lighting }\end{array}$ & $\begin{array}{l}\text { Product idea arose out of dealing with own } \\
\text { user problem and technology } \\
\text { experimentation. }\end{array}$ & $\begin{array}{l}\text { Divergent; } \\
\text { wondering }\end{array}$ & Convergent \\
\hline $\begin{array}{l}\text { 22. Zeus } \\
\text { Music } \\
\text { Software }\end{array}$ & $\begin{array}{l}\text { Idea was developed due to knowledge of } \\
\text { user problems and anticipation of possible } \\
\text { new technologies to meet emerging needs. }\end{array}$ & $\begin{array}{l}\text { Convergent; } \\
\text { analyzing / } \\
\text { concluding }\end{array}$ & $\begin{array}{l}\text { Rather } \\
\text { convergent }\end{array}$ \\
\hline $\begin{array}{l}\text { 23. Conchur } \\
\text { Transportation } \\
\text { Equipment }\end{array}$ & $\begin{array}{l}\text { Product idea has been developed because of } \\
\text { market knowledge and customer problems. }\end{array}$ & $\begin{array}{l}\text { Convergent; } \\
\text { concluding / } \\
\text { understanding }\end{array}$ & $\begin{array}{l}\text { Rather } \\
\text { divergent }\end{array}$ \\
\hline $\begin{array}{l}\text { 24. Daire } \\
\text { Transportation } \\
\text { Equipment }\end{array}$ & $\begin{array}{l}\text { Different ideas came together and fitted to a } \\
\text { specific request during a research project - } \\
\text { leading to the foundation of own venture. }\end{array}$ & $\begin{array}{l}\text { Divergent; } \\
\text { associating }\end{array}$ & Balanced \\
\hline $\begin{array}{l}\text { 25. Endymion } \\
\text { Building } \\
\text { equipment }\end{array}$ & $\begin{array}{l}\text { Direct customer request, which had been } \\
\text { addressed in order to develop a solution. }\end{array}$ & $\begin{array}{l}\text { Convergent; } \\
\text { evaluating / } \\
\text { concluding }\end{array}$ & $\begin{array}{l}\text { Rather } \\
\text { convergent }\end{array}$ \\
\hline $\begin{array}{l}\text { 26. Abaris } \\
\text { Functional } \\
\text { Apparel }\end{array}$ & $\begin{array}{l}\text { Product idea transferred from another } \\
\text { geographical market in combination with } \\
\text { trend scouting. }\end{array}$ & $\begin{array}{l}\text { Divergent; } \\
\text { associating }\end{array}$ & Balanced \\
\hline $\begin{array}{l}\text { 27. Daedalus } \\
\text { Functional } \\
\text { Apparel }\end{array}$ & $\begin{array}{l}\text { Idea arose out of own user need because of } \\
\text { bad experience with existing solutions and a } \\
\text { vision. }\end{array}$ & $\begin{array}{l}\text { Divergent; } \\
\text { imagining }\end{array}$ & Balanced \\
\hline
\end{tabular}


Certainly, it is not divergent thinking alone that plays a role for the identification of new product opportunities. The pre-condition in the majority of those cases was that there was a certain degree of knowledge related to a technology in combination with a more specific problem or need (often hobbies or general interests). Opportunity recognition for new products therefore is predominantly initiated by means of divergent thinking processes. This is especially true for high-technology contexts and when the entrepreneur possesses a proper degree of prior knowledge of technologies, markets or user problem. In addition we calculated the percentage of each expressed cognitive mechanisms (not counting repetitions). We than used the top-level codes of divergent and convergent thinking for each of the mechanisms, e.g., analyzing and evaluating for "convergent", ideating and questioning for "divergent"). Subsequently, we attributed each percentage to a dominant thinking pattern as per coverage of the coded text material: if between $40-60 \%$ of codes are divergent and the rest convergent and vice versa; we put it into the "balanced thinking pattern" category; if more than $60 \%$ of the coded processes would pertain to one or the other mechanism, we categorized it as rather divergent or convergent; and if more than $75 \%$ of the references could be attributed to one or the other thinking mechanisms, we categorized it as clear "convergent" or "divergent" patterns. Figure 2 highlights this expanded view on different opportunity types in relation to the dominant cognitive patterns and technological contexts (black circles $=$ high-tech, white circles $=$ low-tech industries). For simplicity reasons we grouped together pure and rather convergent or divergent patterns.

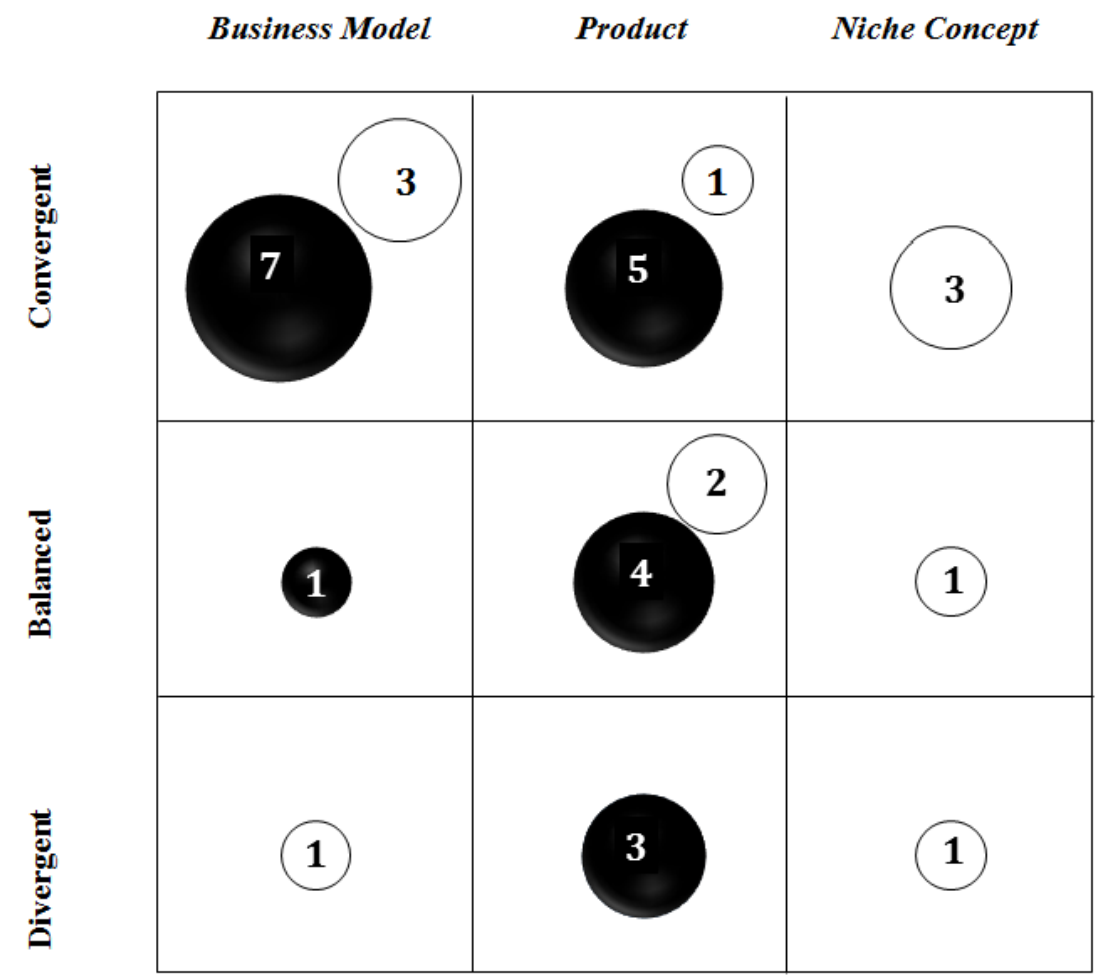

Figure 2. Dominant patterns in relation to opportunity type and technology intensity

\section{Conclusion}

The case study analysis revealed several initial findings. First, new product opportunities can be identified by both ways of thinking triggering thought. The distribution is more or less equal. What influences the initial mechanisms seems to lay more in the personal qualities of the entrepreneur and their way of doing product design and development. Interviewed people with an engineering background predominantly commenced the process with a convergent thought. Those with business or mixed backgrounds have applied both triggering mechanisms equally. 
Second, different thinking patterns were identified not only between different actors but also a long process of opportunity recognition - from convergent over balanced to divergent. Developers in hightech industries use convergent patterns more after they have identified the initial problem, technology or idea. The difference, however, is again bigger when looking at the education and opportunity type. People with engineering and business backgrounds again apply convergent thinking mechanisms, such as evaluating feasibility, analyzing the market, categorizing the problem more often - for engineers even stronger, as they use that type of thought also for both business model and product opportunities. On the contrary, experts with mixed or design backgrounds pursued product opportunities more often applied also more balanced thought. They investigate more time in balanced reasoning: from questioning or re-defining the problem properties, ideating different solution possibilities, imagining desired solutions, re-combination of technologies to evaluating ideas and technologies. We assume that the physical reality of the products supports fostering divergent thinking. When controlling for the education, we found that business and mixed-business educational backgrounds apply more of these business-related strategies. Third, we come to the conclusion that both divergent and convergent thinking play a fundamental role in opportunity recognition. In particular, the hitherto underestimated role of convergent thinking has been identified as an important mechanism. Whether evaluation of a new product idea for its usefulness and feasibility, or analysis of markets with new business models - in almost all cases the entrepreneurs did recognize the inherent market or innovation potential by means of convergent thought.

\section{Implications}

Both convergent and divergent thinking play a fundamental role in identifying new opportunities. Innovative opportunities can be identified both in divergent and convergent ways. In the majority of cases the participants reported alternation of creative generation of new connections and rational analysis of new both information and own ideas - thus what matters is the joint application of both divergent and convergent thinking. However, for one specific type of opportunity - that for new business models - convergent thinking with market and technological analyses, evaluations and both deductive and conductive conclusions are prevailing cognitive processes. In this sample the thinking mode that was adopted more often is convergent; however divergent thinking patterns still plays a fundamental role when establishing new connections for new products.

For future research, those initial, exploratory findings are being validated by means of a large scale investigation. Promising avenues are experimental settings, in which participants could be assigned to both business model and new product opportunities - for both high- and low-technological contexts. Next to looking at the actual cognitive processes, the ability levels of divergent and convergent thinking should be measured, in order to develop solid theory and clear recommendations for practice. This is especially true because as of today, only the divergent thinking ability has shown a positive effect on innovative opportunities, while convergent thinking has not. However, prior studies on cognitive abilities have not emphasized different opportunity types and contexts; which are of utmost importance for innovation education and practice.

\section{References}

Ardichvili, A., Cardozo, R. and Ray, S. (2003), "A theory of entrepreneurial opportunity identification and development", Journal of Business Venturing, Vol. 18 No. 1, pp. 105-123. https://doi.org/10.1016/S08839026(01)00068-4

Arentz, J., Sautet, F. and Storr, V. (2012), "Prior-knowledge and opportunity identification", Small Business Economics, Vol. 41 No. 2, pp. 461-478. https://doi.org/10.1007/s11187-012-9437-9

Baron, R.A., and Ward, T.B. (2004), "Expanding entrepreneurial cognition's toolbox: Potential contributions from the field of cognitive science", Entrepreneurship Theory and Practice, Vol. 28 No. 6, pp. 553-573. https://doi.org/10.1111/j.1540-6520.2004.00064.x

Baron, R.A. (2006), "Opportunity recognition as pattern recognition: How entrepreneurs "connect the dots" to identify new business opportunities”, Academy of Management Perspectives, Vol. 20 No. 1, pp. 104-119. 
Corbett, A.C. (2005), "Experiential Learning Within the Process of Opportunity Identification and Exploitation", Entrepreneurship Theory and Practice, Vol. 29 No. 4, pp. 473-491. https://doi.org/10.1111/j.15406520.2005.00094.x

Corbett, A.C. (2007), "Learning asymmetries and the discovery of entrepreneurial opportunities", Journal of Business Venturing, Vol. 22 No. 1, pp. 97-118. https://doi.org/10.1016/j.jbusvent.2005.10.001

Cropley, A. (2006), "In Praise of Convergent Thinking”, Creativity Research Journal, Vol. 18 No. 3, pp. 391-404. https://doi.org/10.1207/s15326934crj1803_13

Cropley, D.H. and Cropley, A.J. (2015), The psychology of innovation in organizations, Cambridge University Press, New York.

Dimov, D. (2007), "From opportunity insight to opportunity intention: The importance of person-situation learning match”, Entrepreneurship Theory and Practice, Vol. 31 No. 4, pp. 561-583. https://oi.org/10.1111/j.15406520.2007.00188.x

Dimov, D. (2011), "Grappling with the Unbearable Elusiveness of Entrepreneurial Opportunities", Entrepreneurship Theory and Practice, Vol. 35 No. 1, pp. 57-81. https://doi.org/10.1111/j.15406520.2010.00423.x

Dyer, J.H., Gregersen, H.B. and Christensen, C. (2008), "Entrepreneur Behaviors, Opportunity Recognition, and the Origins of Innovative Ventures", Strategic Entrepreneurship Journal, Vol. 2 No. 4, pp. 317-338. https://doi.org/10.1002/sej.59

Eisenhardt, K.M. (1989), "Building Theories from Case-Study Research”, The Academy of Management Review, Vol. 14 No. 4, pp. 532-550. https://doi.org/10.2307/258557

Eisenhardt, K.M. and Graebner, M.E. (2007), "Theory Building from Cases: Opportunities and Challenges", Academy of Management Journal, Vol. 50 No. 1, pp. 25-32.

Gemmell, R.M., Boland, R.J. and Kolb, D.A. (2012), "The Socio-Cognitive Dynamics of Entrepreneurial Ideation", Entrepreneurship Theory and Practice, Vol. 36 No. 5, pp. 1053-1073. https://doi.org/10.1111/j.1540-6520.2011.00486.x

Gielnik, M.M., Frese, M., Graf, J.M. and Kampschulte, A. (2012), "Creativity in the opportunity identification process and the moderating effect of diversity of information”, Journal of Business Venturing, Vol. 27 No. 5 , pp. 559-576.

Grégoire, D.A. and Shepherd, D.A. (2011), "Technology-Market Combinations and the Identification of Entrepreneurial Opportunities: An Investigation of the Opportunity-Individual Nexus", Academy of Management Journal, Vol. 55 No. 4, pp. 753-785.

Grégoire, D.A., Corbett, A.C. and McMullen, J.S. (2011), “The Cognitive Perspective in Entrepreneurship: An Agenda for Future Research”, Journal of Management Studies, Vol. 48 No. 6, pp. 1443-1477.

Grégoire, D.A., Cornelissen, J., Dimov, D. and van Burg, E. (2015), "The Mind in the Middle: Taking Stock of Affect and Cognition Research in Entrepreneurship", International Journal of Management Reviews, Vol. 17 No. 2, pp. 125-142. https://doi.org/10.1111/ijmr.12060

Hansen, D.J., Lumpkin, G.T. and Hills, G.E. (2011), “A multidimensional examination of a creativity-based opportunity recognition model”, International Journal of Entrepreneurial Behaviour \& Research, Vol. 17 No. 5, pp. 515-533. https://doi.org/10.1108/13552551111158835

Kirzner, I.M. (1999), "Creativity and/or alertness: A reconsideration of the Schumpeterian entrepreneur", The Review of Austrian Economics, Vol. 11 No. 1-2, pp. 5-17. https://doi.org/10.1023/A:1007719905868

Ko, S. and Butler, J.E. (2006), "Prior knowledge, bisociative mode of thinking and entrepreneurial opportunity identification", International Journal of Entrepreneurship and Small Business, Vol. 3 No. 1, pp. 3-16. https://doi.org/10.1504/IJESB.2006.008659

Miles, M.B. and Huberman, A.M. (1984), Qualitative data analysis, Sage Publications, Beverly Hills, CA.

Mitchell, R.K., Busenitz, L., Lant, T., McDougall, P.P., Morse, E.A. and Smith, J.B. (2004), “The distinctive and inclusive domain of entrepreneurial cognition research", Entrepreneurship Theory and Practice, Vol. 28 No. 6, pp. 505-518. https://doi.org/10.1111/j.1540-6520.2004.00061.x

Shane, S. and Venkataraman, S. (2000), "The promise of entrepreneurship as a field of research", Academy of Management Review, Vol. 25 No. 1, pp. 217-226. https://doi.org/10.2307/259271 
Siegel, D.S. and Renko, M. (2012), "The role of market and technological knowledge in recognizing entrepreneurial opportunities”, Management Decisions, Vol. 50 No. 5, pp. 797-816. https://doi.org/10.1108/00251741211227500

Ucbasaran, D., Westhead, P. and Wright, M. (2008), "Opportunity Identification and Pursuit: Does an Entrepreneur's Human Capital Matter?”, Small Business Economics, Vol. 30 No. 2, pp. 153-173. https://doi.org/10.1007/s11187-006-9020-3

Ward, T.B. (2004), “Cognition, creativity, and entrepreneurship”, Journal of Business Venturing, Vol. 19 No. 2 , pp. 173-188. https://doi.org/10.1016/S0883-9026(03)00005-3

Yin, R.K. (2009), Case Study Research: Design and Methods, 4th ed., Sage.

Dr.-Ing. Christian Marxt, Private Docent

ETH Zurich, MTEC

Scheuchzerstrasse 196, 8057 Zurich, Switzerland

Email: cmarxt@ethz.ch 